\title{
Avebury: a Late Anglo-Saxon burh?
}

\section{ANDREW REYNOLDS*}

FIGURE 1. Extract from the RCHME survey of Avebury showing the earthworks of the suggested burh (red), the underlying settlement (black) and the location of 9thcentury radiocarbon determinations: $1=\mathrm{C} .830 \mathrm{cal} \mathrm{AD}, 2=\mathrm{C} .886 \mathrm{cal} \mathrm{AD}$. (Photo $@$ Crown copyright.)

Re-assessment of the Anglo-Saxon archaeology of Avebury, North Wiltshire, suggests that a fortified settlement, or burh, was established on the western side of the henge during the 9 th century AD. A sub-square enclosure, internally divided into regular plots, can be discerned from the recent RCHME survey (FIGURE 1) of Avebury's earthworks and the modern form of the settlement (FIGURE 2).

\section{A town plan?}

The RCHME plan shows a sub-square enclosure with a central street, termed a herepa (Old English 'army road'), running west-east through the settlement, which in turn overlies an elliptical plan form discernible on the RCHME plan (FIGURE 1). From east to west the proposed burh measures $270 \mathrm{~m}$, the western side is $300 \mathrm{~m}$ in length, whilst the eastern side is shorter at $200 \mathrm{~m}$. Individual plots within the enclosure are perpendicular to the main street. A radiocarbon determination, from a pit filled with grain from the school site excavations of 30 years ago, of $1200 \pm 80 \mathrm{BP}$ (HAR 760454) C. $830 \mathrm{cal}$ AD shows occupation within the confines of the burh in the 9th century, whilst a further radiocarbon date of $1160 \pm 80 \mathrm{BP}$ (OxA 1220) c.886 cal AD has been obtained

FIGURE 2. Vertical aerial photograph showing the proposed burh in relation to the Avebury henge. (Photograph (C) Cambridge University Collection of Air Photographs.)
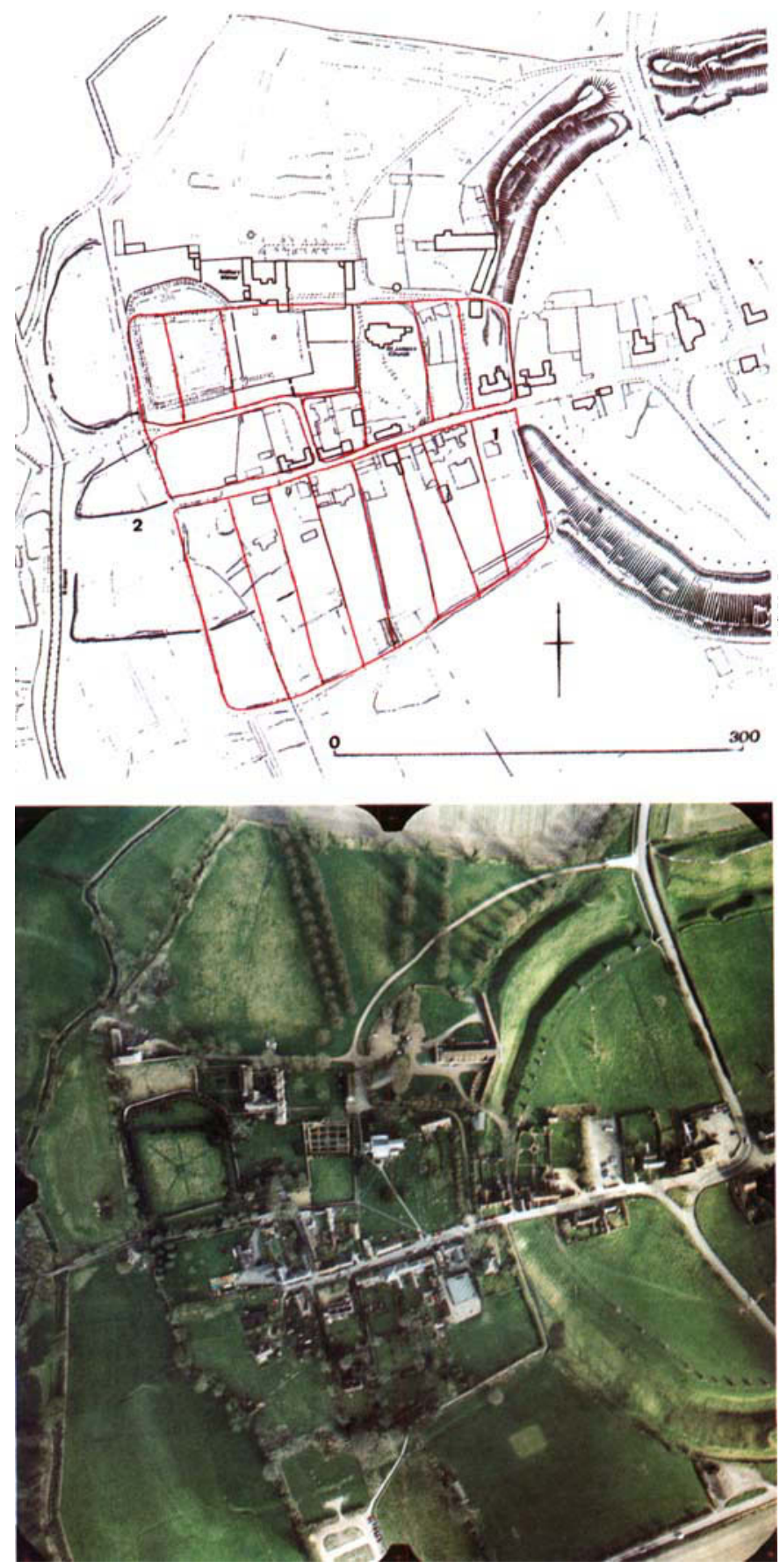

* Department of Archaeology, King Alfred's College, Winchester so22 4NR, England. a.reynolds@wkac.ac.uk ANTIQUITY 75 (2001): 29-30 
from deposits outside the west entrance to the burh (Evans et al. 1993: table 1) (FIGURE 1). The suggested defensive circuit remains undated.

The closest parallels are the planned fortified towns built or refurbished particularly by the West Saxon kings from the late 9th through to the early 11th century in England and documented in the Burghal Hidage list. The place-name Avebury is best read as 'fortified place by the Avon'. Indeed, other English forts are known from place-name evidence, incidental documentary references and topographical inference at places like Newark, Nottinghamshire and Witham, Essex (Kinsley 1993; Rodwell 1993) that compare well with Avebury in terms of scale and layout.

A remarkable status for the Avebury settlement in the Late Anglo-Saxon period is further suggested the presence of a substantial masonry church dated to $c$. $1000 \mathrm{AD}$. The northwest corner of the present nave is formed of side alternate megalithic quoins with an ex situ incised slab with a floral design forming an integral part of the west wall, suggestive of a yet earlier church. It could be suggested that the displaced sculpture belongs to the period of burh construction and that the standing fabric represents reconstruction or rebuilding before the decline of the settlement to one of a more rural character. The scale of the building exceeds the size of a typical 'estate'type church, where nave dimensions are rarely more than $c .8 \mathrm{~m} \mathrm{x} 4 \mathrm{~m}$; St James' nave, by contrast, measures $13 \mathrm{~m} \times 6.7 \mathrm{~m}$ (Semple forthcoming). Domesday Book records only the church and its holding of 2 hides at Aveberie, but this reveals that St James was very likely of minster status, at least by the end of the Anglo-Saxon period.

Although the classic burhs, such as Wallingford, Cricklade and Oxford, are of a comparatively large size, certain of the settlements listed in the Burghal Hidage are significantly smaller. Forts at Wilton in Wiltshire as defined by Jeremy Haslam and Twineham (Christchurch), Dorset by David Hill, for example, are almost identical in extent to Avebury (Haslam 1984b: 126, figure 52; Keen 1984: 234, figure 81). The classic burhs usually allow a generous area inside each fort, presumably to cope with rapid influxes from the surrounding area during times of civil unrest; a function served, perhaps, by the interior of the Avebury henge.

\section{A failed urban enterprise?}

At Avebury, the combination of scale, plan-form and archaeology strongly suggest a later 9 th-century urban speculation. Although one proceeds with caution when referencing the documentary record, Viking activity in the immediate vicinity is noted under the years 1006 and 1010 in the Anglo-Saxon Chronicle. The language of these particular chronicle entries describes the Vikings on violent campaign and, although we should expect some West Saxon bias, the basic sequence of events need not be doubted. Avebury's failure to develop into a town may have been affected, or indeed curtailed, by Viking Activity, but the growth of nearby market towns, Calne to the west and Marlborough to the east, the latter itself a further contender for an Avebury-type burh, might equally have dictated decline.

Acknowledgements. I am grateful to Ros Cleal, Rosie Edmunds, Charles Harward, Gabriel Pepper, Sarah Semple and the Avebury Archaeological and Historical Research Group (AAHRG) for discussions on Avebury and to Catherine Sweeney for providing the calibrated radiocarbon date from the school site excavations. Acknowledgement is also due to the help and advice of Mark Bowden and David Field. This study of Avebury forms part of an on-going and expanding research project investigating the landscape context of Anglo-Saxon civil defence in the Viking Age.

\section{References}

EVANS, J., S. LIMBrey, I. MÁtÉ \& R. MOUNTI. 1993. An environmental history of the Upper Kennet Valley, Wiltshire, for the last 10,000 years, Proceedings of the Prehistoric Society 59: $139-95$.

HASLAM, J. (ed.) 1984a. Anglo-Saxon towns in southern England. Chichester: Phillimore.

1984b. The towns of Wiltshire, in Haslam (ed.): 87-147.

KEENE, L. 1984. The towns of Dorset, in Haslam (ed.): 203-47.

KinSLEY, A. 1993. Excavations on the Saxo-Norman town defences at Slaughter House Lane, Newark-on-Trent, Nottinghamshire, Transactions of the Thoroton Society of Nottinghamshire 97: 14-63.

RUDWELL, W. 1993. The origins and early development of Witham, Essex. A study in settlement and fortification, prehistoric to medieval. Oxford: Oxbow. Monograph 26.

SEMPLE, S. In preparation. The Anglo-Saxon Church of St James at Avebury. 